\title{
Effects of different dietary ratio of metabolizable glucose and metabolizable protein on growth performance, rumen fermentation, blood biochemical indices and ruminal microbiota of 8 to 10-month-old dairy heifers
}

\author{
Jie Sun ${ }^{1}$, Jinhao Xu${ }^{1}$, Rufang Ge${ }^{1}$, Mengzhi Wang ${ }^{1}$, Lihuai $\mathbf{Y u}^{1}$, and Hongrong Wang ${ }^{1, *}$
}

* Corresponding Author: Hongrong Wang Tel: +86-514-87997196, Fax: +86-514-87350440,

E-mail: hrwang@yzu.edu.cn

'College of Animal Science and Technology, Yangzhou University, Yangzhou, Jiangsu 225009, China

\section{ORCID}

Jie Sun

https://orcid.org/0000-0002-7260-7931 Jinhao Xu

https://orcid.org/0000-0001-5910-1875 Rufang Ge

https://orcid.org/0000-0001-6076-1491

Mengzhi Wang

https://orcid.org/0000-0002-4559-3044

Lihuai Yu

https://orcid.org/0000-0001-7267-0917

Hongrong Wang

https://orcid.org/0000-0002-4980-1082

Submitted Dec 8, 2017; Revised Jan 2, 2018; Accepted Jan 18, 2018
Objective: The aim of this experiment was to evaluate the effects of different dietary ratio of metabolizable glucose (MG) to metabolizable protein (MP) on growth performance, blood metabolites, rumen fermentation parameters and the ruminal microbial community of 8 to 10-month-old heifers.

Methods: A total of 24 Holstein heifers weighing an average of $282.90 \mathrm{~kg}$ ( 8 month of age) were randomly assigned to four groups of six. The heifers were fed one of four diets of different dietary MG/MP (0.97, 1.07, 1.13, and 1.26).

Results: The results showed that the ratio of MG/MP affected the growth performance, blood metabolites, rumen fermentation parameters and the ruminal microbial community of heifers. The average daily gain of heifers was enhanced by increasing the ratio of $\mathrm{MG} / \mathrm{MP}$ $(p<0.05)$. The concentration of blood urea nitrogen, cholesterol, and low density lipoprotein cholesterol as well as the concentration of total volatile fatty acid in the rumen fluid of heifers decreased with the improvement in the ratio of dietary MG/MP $(\mathrm{p}<0.05)$. However, the relative amount of Ruminococcus albus and Butyrivibrio fibrisolvens in the rumen of heifers was increased significantly $(p<0.05)$ when the dietary MG/MP increased. At the same time, with the improvement in dietary MG/MP, the amount of Fibrobacter succinogenes increased $(\mathrm{p}=0.08)$.

Conclusion: A diet with an optimal ratio (1.13) of MG/MP was beneficial for the improvement of growth, rumen fermentation, dietary protein and energy utilization of 8 to 10-monthold dairy heifers in this experiment.

Keywords: Metabolizable Glucose; Metabolizable Protein; Dairy Heifers; Rumen Microbe; Fermentation Parameters

\section{INTRODUCTION}

A cow from birth to their first calf delivery is usually called a heifer [1]. Heifers play an important role in the dairy industry. The period in which cows are heifers lasts 22 to 27 months, and the cost of heifers accounts for $20 \%$ of the total animal costs [2]. So much importance is attached to the breeding of heifers in developed countries that the delivery date is controlled within 14 months and the milk production goes beyond 8 tons [3]. However, heifer rearing has not attracted enough attention for most dairy herd management in China. Because of the lack of experience and related feeding guidance, the delivery date of heifers was longer and the milk production was lower. Therefore, a proper assessment and evaluation of the feeding of heifers and recommendations for diet formulation are required. Nutritional factors are one of the most important factors that affect the breeding of heifers, and 
protein and energy content as well as their balance in a heifer's diet cannot be ignored [4].

Dietary nutrient density and structure between birth and puberty are critical for growing heifers. Of all the dietary nutrients, glucose metabolism in ruminants is very different from mono-gastric animals. The sources of glucose in ruminants were derived from dietary rumen bypass nutrition as well as endogenous syntheses from propionate and recycled glucogenic amino acids. There was some evidence that the efficiency of nitrogen in a low protein diet was improved by increasing dietary carbohydrates [5]. The utilization efficiency of diets was improved by increasing the level of carbohydrates $(\mathrm{C} 3+\mathrm{C} 6)$ in the diets [6]. Ruminants provided with exogenous glucose can reduce the synthesis of endogenous glucose, which contributes to conserving glucogenic amino acids [7]. Li et al [8] reported that the utilization efficiency of nitrogen was improved greatly by pouring glucose into the abomasum. A novel index based on ruminant glucose metabolism called metabolizable glucose (MG) was proposed initially by $\mathrm{Lu}$ [9]. It is essential to study the dietary levels of MG to provide suitable energy for heifers.

Growing heifers require protein to support maintenance, growth and pregnancy. Unbalanced dietary protein is not only a waste of resources but also leads to an increase in environmental pollution [10]. Because the rumen contains enzymes, dietary protein has been divided into rumen degradable protein (RDP) and rumen undegradable protein (RUP). RDP is utilized by rumen microbes and generates rumen microbial protein (MCP). As such, metabolizable protein (MP) consists of RUP, MCP and little endogenous protein. Feng [11] suggested that adding extra RUP to meet the requirements of MP for high productivity was necessary. The potential for increased growth rates to reduce age at first calving should be fulfilled by increasing crude protein (CP) intake. Therefore, the ratio of $\mathrm{CP}$ to energy should be higher for rapidly growing heifers [12]. The new NRC [13] guidelines for protein relative to energy seemed to be adequate for optimal mammary development of heifers [4]. Until now, less information was available on the synergistic interactions between MG and MP for growing dairy heifers. So the most suitable energy and protein requirements of heifers can be measured by the combination MG with MP. Therefore, the objective of this experiment was to attempt to determine the effect of four diets consisting of different dietary MG/MP ratios on the growth performance, blood metabolites, rumen fermentation parameters, and the rumen microbial community as well as the optimal dietary MG/MP level for 8 to 10-month-old heifers.

\section{MATERIALS AND METHODS}

\section{Experimental design}

Animal care and procedures were approved under established standards by the Committee of Yangzhou University on Animal Care and Ethics (20140510). Twenty-four Holstein heifer calves with similar genetic merits, age ( 8 months), and body weight $(282.90 \pm 17.93 \mathrm{~kg}$; mean \pm standard deviation) were randomly assigned to four treatments. All heifers were housed and managed at the Yangzhou University experimental farm. Heifers were fed one of four diets, which were chemically identical but included different ratios of MG/MP, as shown in Table 1. Feed bunks were located along the front of each indoor pack area. Water was freely available to the heifers through a water bowl in each pen. Total mixed rations were fed at 0800 hours and 1700 hours to ensure ad libitum consumption. According to the leftover diets and body weight, a $10 \%$ increase was added every 15 days. An adjustment period of 15 days allowed the heifers to adjust to the diets, and the experimental period was 60 days.

\section{Feeds and diets}

Diets were formulated to meet the nutrient requirements of

Table 1. Dietary ingredients used, final chemical compositions and nutrient levels of the four diets fed to 8 to 10-month-old heifers

\begin{tabular}{|c|c|c|c|c|}
\hline \multirow{2}{*}{ Items } & \multicolumn{4}{|c|}{ Dietary treatments (MG/MP) } \\
\hline & $A(0.97)$ & $B(1.07)$ & $C(1.13)$ & $\mathrm{D}(1.26)$ \\
\hline \multicolumn{5}{|l|}{ Ingredients of DM (\%) } \\
\hline Wild ryegrass hay & 24.00 & 24.00 & 24.00 & 24.00 \\
\hline Corn silage & 26.00 & 26.00 & 26.00 & 26.00 \\
\hline Ground corn grain & 17.00 & 24.00 & 27.60 & 36.00 \\
\hline Soybean meal & 3.10 & 9.20 & 6.10 & 8.40 \\
\hline Wheat bran & 15.60 & 10.60 & 7.30 & 0.70 \\
\hline DDGS & 11.30 & 3.20 & 6.00 & 1.90 \\
\hline Calcium fatty acid & 1.50 & 0.80 & 0.70 & 0 \\
\hline $\mathrm{CaHPO}_{4}$ & 0.05 & 0.30 & 0.40 & 0.60 \\
\hline $\mathrm{NaHCO}_{3}$ & 0.50 & 0.40 & 0.40 & 0.80 \\
\hline Limestone & 0.40 & 0.50 & 0.50 & 0.60 \\
\hline $\mathrm{NaCl}$ & 0.50 & 0.50 & 0.50 & 0.50 \\
\hline Premix ${ }^{1)}$ & 0.50 & 0.50 & 0.50 & 0.50 \\
\hline \multicolumn{5}{|l|}{ Nutrient content } \\
\hline $\mathrm{NE}_{\mathrm{L}}(\mathrm{MJ} / \mathrm{kg})^{2)}$ & 6.73 & 6.73 & 6.73 & 6.73 \\
\hline$M G$ & 9.77 & 10.77 & 11.41 & 12.71 \\
\hline MP & 10.10 & 10.08 & 10.10 & 10.09 \\
\hline MG/MP & 0.97 & 1.07 & 1.13 & 1.26 \\
\hline ADF & 21.25 & 19.71 & 19.71 & 18.62 \\
\hline NDF & 41.00 & 37.05 & 36.42 & 33.18 \\
\hline $\mathrm{Ca}$ & 0.61 & 0.62 & 0.61 & 0.62 \\
\hline$P$ & 0.46 & 0.46 & 0.45 & 0.43 \\
\hline
\end{tabular}

DM, dry matter; DDGS, distillers dried grains with solubles; $M G$, metabolizable glucose; MP, metabolizable protein; ADF, acid detergent fiber; NDF, neutral detergent fiber.

1) The premix provided the following per $\mathrm{kg}$ of diet: Vit $A$ 8,000 IU; Vit $D_{3} 1,000 \mathrm{IU}$; Vit E 25 mg; Cu(as copper sulfate) 10 mg; Fe(as ferrous sulfate) 24 mg; Zn(as zinc sulfate) $42 \mathrm{mg}$; Co(as cobalt sulfate) $0.24 \mathrm{mg}$; Se(as sodium selenite) $0.16 \mathrm{mg}$; nicotinic acid $36 \mathrm{mg}$; choline 1,000 mg.

${ }^{2)} \mathrm{NE}_{\mathrm{L}}$ was the calculated value of feedstuffs from NRC [13] equations: $\mathrm{NE}_{L}(\mathrm{MJ} / \mathrm{kg})$ $=0.703 \times \mathrm{ME}(\mathrm{MJ} / \mathrm{kg})-0.045$, and others were measured values. 
heifers according to NRC [13] (Table 1). The diets consisted of $50 \%$ forage and $50 \%$ concentrate (DM basis). The MG level of ingredients was calculated with the formula proposed by $\mathrm{Lu}[9]$ :

$$
\mathrm{MG}(\mathrm{g} / \mathrm{kg})=\mathrm{POEG}+\mathrm{BSEG}=0.09 \times \mathrm{k}_{1} \times \mathrm{P}_{\mathrm{r}}+0.9 \times \mathrm{k}_{2} \times \mathrm{BS}
$$

Where POEG refers to the glucose that was generated from propionic acid in the rumen, BESG refers to the glucose provided by ruminant bypass starch, $\mathrm{k}_{1}$ refers to the absorptivity of propionic acid in rumen, $\mathrm{P}_{\mathrm{r}}$ refers to the yield of propionic acid in rumen, $\mathrm{k}_{2}$ is the absorptivity of ruminal bypass starch in the intestine and BS refers to the amount of ruminal bypass starch. $k_{1}$ was measured according to the method of Han et al [14], using a gas chromatograph (GC-17 A, Shimadzu, Tokyo, Japan), with a 15-m Supelco Nukol silica capillary column. The value of $\mathrm{P}_{\mathrm{r}}$ equals the concentration of propionic acid times rumen liquid volume. $\mathrm{k}_{2}$ and BS were measured with the nylon bag method of Lan et al [15]. First collecting ruminant bypass residue, then putting nylon bag with small intestinal fluid freeze dried powder and ruminant bypass residue into $\mathrm{McDougall}$ buffer at $39^{\circ} \mathrm{C}$ for analysis. The MG levels of ground corn grain, soybean meal, wheat bran, distillers dried grains with solubles (DDGS), corn silage and wild ryegrass hay were $25.60,8.22,9.45,10.08,5.69$, and 4.46 , respectively. The MG levels of the four diets were weighted data results, they were calculated based on the MG levels of the ingredients.

The MP levels of the ingredients were calculated by the formula proposed by NRC [13]:

$$
\mathrm{MP}(\%)=0.64 \times \mathrm{MCP}(\%)+0.8 \times \mathrm{RUP}(\%) \times \mathrm{CP}(\%)
$$

MCP was estimated with a formula according to NRC [13], $\mathrm{MCP}(\%)=0.91 \times \mathrm{ME}(\mathrm{MJ} / \mathrm{kg})$. Crude protein was measured with a FOSS N Analyzer (KT260, Foss Co., Hilleroed, Denmark). RUP was measured via the nylon bag method [16] in three Holsten cows with permanent fistulas from the Yangzhou university experimental farm. Putting nylon bag with an ingredient into rumen abdomen sac after feeding $2 \mathrm{~h}$, the ingredient was freeze-dried, milled to coarse powder and fitted with $2.5 \mathrm{~mm}$ screen. Taking the nylon bag out at 2, 6, 12, $16,24,36,48 \mathrm{~h}$ to measure proportion of decomposition. The MP levels of ground corn grain, soybean meal, wheat bran, DDGS, corn silage and wild ryegrass hay were $11.43 \%, 21.39 \%$, $9.33 \%, 20.52 \%, 7.85 \%$, and $7.01 \%$, respectively. The MP levels of the four diets were weighted data results. They were calculated by the MP level of the ingredients. Our previous study demonstrated that the most suitable dietary MP level for 8 to 10 -month-old heifers was $10.09 \%$ [17], so the MP levels in this experiment were $10.09 \%$ approximately and remained the same in the four diets.
Feed intake and growth measurements

Intakes of each heifer were recorded daily throughout the study period by weighing the amount of feed supply and refused. Feed samples were analyzed for dry matter (DM) with oven drying at $65^{\circ} \mathrm{C}$ for 48 hours. These data were used to calculate daily dry matter intake (DMI). DMI was calculation of amount of supply subtracts the refused. At the beginning (the first day), middle (the thirtieth day), and final day (the sixtieth day) of the trial, all heifers were weighed and measured for body height, body length, heart girth, abdominal girth and rump length using a measuring tape and a measuring stick.

\section{Blood metabolite measurements}

Blood was collected in approximately $10 \mathrm{~mL}$ samples from each heifer via venipuncture $1 \mathrm{~h}$ after the morning feeding at final day (the sixtieth day) of the trial. The blood samples were centrifuged at 3,000 $\times$ g for 10 minutes, and the serum was transferred to $5 \mathrm{~mL}$ centrifuge tubes. Concentrations of glucose (GLU), blood urea nitrogen (BUN), cholesterol (CHOL), triglycerides, high density lipoprotein cholesterol (HDL-C), and low density lipoprotein cholesterol in serum were measured with a Synchron Clinical System Autoanalyzer (DXC800, Beckman Company, Topeka, KS, USA) using bovine kits purchased from Beckman.

\section{Determination of rumen fermentation parameters}

Rumen contents were sampled with an esophageal tube vacuum pump sampling device (Anscitech Company, Wuhan, China) two hours after the morning feeding 15 and $45 \mathrm{~d}$ into the experimental period. Approximately $50 \mathrm{~mL}$ of rumen digesta was collected after removing saliva from the top of sampling bottle and then filtered through four layers of cheesecloth to obtain strained rumen fluid. The $\mathrm{pH}$ of the rumen fluid was measured immediately after collection using a handheld pHS-3C meter (Baojing Co., Zhengzhou, China). The rumen ammonia concentration was measured by the method of Broderick and Kang [18]. Rumen fluid was filtered, centrifuged and 25\% metaphosphoric acid solution was added before sample introduction. Concentrations of acetic acid, propionic acid, isobutyric acid, butyric acid, isovaleric acid, and valeric acid were measured by Headspace gas chromatography (7890A-G1888, Agilent Technologies Inc., Palo Alto, CA, USA). The temperature of the injection port was set to $220^{\circ} \mathrm{C}$, and the detector temperature was $250^{\circ} \mathrm{C}$. Temperature programming of the column included an initial temperature of $60^{\circ} \mathrm{C}$ that was heated up at a speed of $20^{\circ} \mathrm{C} / \mathrm{min}$ to $190^{\circ} \mathrm{C}$, then maintained for 3 minutes.

\section{Determination of the relative amount of the rumen microbial community}

The DNA of the rumen microbes was extracted with a repeated freeze-thaw method [19]. The DNA concentrations 
of rumen microbes were measured by a Relative Quantification Applied Biosystems 7500 Fast Real-Time PCR System (Applied Biosystems Inc., Waltham, MA, USA) using bovine kits purchased from Tiangen (FP205, Tiangen Biotech (Beijing) Co., LTD, Beijing, China). The relative amounts of the target gene were calculated using the $2^{-\Delta \Delta \mathrm{Ct}}$ method [20]. The gene primer sequences of the rumen microbes for real-time polymerase chain reaction are shown in Table 2.

\section{Statistical analysis}

All data were analyzed using PROC MIXED in SAS (version 9.1, SAS Institute, Inc., Cary, NC, USA). In the model, heifers were the random effect and the four diets with different MG/ MP were the fixed effects. Polynomials were constructed and degrees of freedom were determined by the Kenward-Roger method, as reported by Littell et al [21]. All data were presented as least squares means with their standard error of the mean throughout. Significance was considered at $\mathrm{p}<0.05$, and a trend was considered to exist if $0.05<\mathrm{p} \leq 0.10$ using Duncan's new multiple range test.

\section{RESULTS AND DISCUSSION}

Body growth and development of the heifers

Dairy heifer growth body size and average daily gain (ADG) at the first calving are regarded as an important management target for the future of heifers because both can affect future milk yield potential [22]. In the current trial, the ADG of heifers increased as the dietary MG/MP increased $(\mathrm{p}<0.05)$ (Table $3)$. And there were no significant $(p>0.05)$ effects of the treat-

Table 2. Primer sequences for polymerase chain reaction of rumen bacteria

\begin{tabular}{|c|c|c|c|}
\hline Rumen bacteria & Primer sequence $\left(5^{\prime}-3^{\prime}\right)$ & Annealing temp $\left({ }^{\circ} \mathrm{C}\right)$ & Amplification size (bp) \\
\hline \multirow[t]{2}{*}{ Bacterial 16s rDNA V3 } & 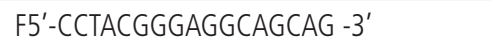 & 54 & 181 \\
\hline & R5'-ATTACCGCGGCTGCTGG-3' & & \\
\hline \multirow[t]{2}{*}{ Fibrobacter succingenes } & F5'-GGCGGGATTGAATGTACCTTGAGA-3' & 60 & 204 \\
\hline & R5'-TCCGCCTGCCCCTGAACTATC-3' & & \\
\hline \multirow[t]{2}{*}{ Streptococcus bovis } & F5'-AAGGCTGAAACTCAAAGG-3' & 52 & 247 \\
\hline & R5'-GTGCCCAACTCAATGATGGCAACTA-3' & & \\
\hline \multirow[t]{2}{*}{ Ruminococcus albus } & F5'-GTTTTAGGATTGTAAACCTCTGTCTT-3' & 63 & 270 \\
\hline & R5'-CCTAATATCTACGCATTTCACCGC-3' & & \\
\hline \multirow[t]{2}{*}{ Ruminococcus flavefaciens } & F5'-GATGCCGCGTGGAGGAAGAAG-3' & 60 & 286 \\
\hline & R5'-CATTTCACCGCTACACCAGGAA-3' & & \\
\hline \multirow[t]{2}{*}{ Butyrivibrio fibrisolvens } & F5'-TAACATGAGAGTTTGATCCTGGCTC-3' & 60 & 136 \\
\hline & R5'-CGTTACTCACCCGTCCGC-3' & & \\
\hline
\end{tabular}

Table 3. Effects of increasing dietary MG/MP ratio on growth performance and DMl of 8 to 10-month-old heifers

\begin{tabular}{|c|c|c|c|c|c|c|}
\hline \multirow{2}{*}{ Items } & \multicolumn{4}{|c|}{ Dietary treatments ${ }^{1)}$ (MG/MP) } & \multirow{2}{*}{ SEM } & \multirow{2}{*}{ p-value } \\
\hline & $A(0.97)$ & B (1.07) & $C(1.13)$ & $\mathrm{D}(1.26)$ & & \\
\hline Initial BW (kg) & 283.42 & 282.58 & 282.25 & 283.33 & 7.74 & 0.99 \\
\hline Final BW (kg) & 321.12 & 330.19 & 345.69 & 330.52 & 8.65 & 0.81 \\
\hline $\operatorname{ADG}(\mathrm{kg} / \mathrm{d})$ & $0.63^{b}$ & $0.79^{b}$ & $1.06^{\mathrm{a}}$ & $0.79^{b}$ & 0.05 & $<0.01$ \\
\hline \multicolumn{7}{|c|}{ Body height $(\mathrm{cm})$} \\
\hline Initial & 114.33 & 117.00 & 115.33 & 115.80 & 0.84 & 0.76 \\
\hline Final & 119.50 & 119.33 & 120.00 & 120.50 & 0.89 & 0.97 \\
\hline \multicolumn{7}{|c|}{ Body length $(\mathrm{cm})$} \\
\hline Initial & 140.33 & 138.67 & 139.50 & 139.67 & 1.14 & 0.97 \\
\hline Final & 142.80 & 141.83 & 148.50 & 144.17 & 1.04 & 0.11 \\
\hline \multicolumn{7}{|l|}{ Heart girth $(\mathrm{cm})$} \\
\hline Initial & 157.33 & 158.17 & 156.00 & 159.17 & 1.56 & 0.92 \\
\hline Final & 163.50 & 163.83 & 163.17 & 162.67 & 1.57 & 0.99 \\
\hline \multicolumn{7}{|c|}{ Abdominal girth $(\mathrm{cm})$} \\
\hline Initial & 178.67 & 179.83 & 182.50 & 179.67 & 2.05 & 0.93 \\
\hline Final & 190.00 & 191.50 & 194.00 & 188.33 & 2.17 & 0.84 \\
\hline DMI (kg/d) & 8.21 & 8.29 & 8.25 & 8.23 & 0.17 & 0.99 \\
\hline
\end{tabular}

MG, metabolizable glucose; MP, metabolizable protein; DMI, dry matter intake; SEM, standard error of the mean; BW, body weight; ADG, average daily gain.

1) Treatments were assigned to the four diets: MG/MP $=0.97,1.07,1.13$, and 1.26.

${ }^{a b}$ Different superscripts within the same row indicate a significant difference $(p<0.05)$. 
ments on DMI, initial body weight (BW) and final BW. Heifers could achieve daily BW gains of approximately 1,000 g from 100 to $300 \mathrm{~kg}$ BW without a negative effect on future milk yield if the intakes of CP were in the range of $90 \%$ to $100 \%$ of the NRC [23] recommendations [24]. The reason for increasing BW could be explained based on the fact that a balance between glucose and amino acids in the diet is critical factor for growing heifers. Amino acid nutritional status may depend on the status of glucose supply in ruminants. Thus, only when the energy supply was matched, can amino acids be used for protein synthesis [25]. Sun et al [26] reported that an optimal MG/MP equilibrium value was 1.07 for growing goats. And $\mathrm{Su}$ [27] reported that increasing dietary MG/MP can increase the portal amino acid flux in the livers of goats as well as the synthesis efficiency of muscle protein and the deposit efficiency of total nitrogen. In this study, the maximal ADG was obtained when the dietary MG/MP is 1.13 , and we found different MG/MP ratios and ADG values were strongly correlated $\left(\mathrm{ADG}=-13.626+25.302(\mathrm{MG} / \mathrm{MP})-10.962(\mathrm{MG} / \mathrm{MP})^{2}\right.$, $\left.r^{2}=0.864, \mathrm{p}<0.05\right)$. Thus, we suppose the optimal MG/MP equilibrium value for 8 to 10 -month-old heifers might be 1.13. There was no differences among the treatments in terms of body length, body height, and heart girth as well as other performance indices ( $>0.05)$, and the reason for this might be that the skeletons of heifers grow slowly after nine months of age [1]. Some studies showed that the MG level in the diet had no significant effect on the BW and DMI, but it may promote the ADG of heifer herds [28]. The present study obtained similar results and DMI was not significantly affected by MG/ MP ratio in the diet; this is probably a result of the same MP value we provided.

\section{Blood biochemical indices}

No effects were observed on GLU concentrations as dietary MG/MP increased, which is shown in Table 4. The reason for this outcome might be that insulin can regulate the glucose level of plasma and remain relatively stable. Murphy et al [29] reported no difference in serum glucose, but observed a lower insulin concentration throughout the feeding period for ad libitum-fed steers whose intake was restricted 30\%. Jenny and Polan [30] observed elevated plasma glucose and insulin in cows fed a high-concentrate diet compared with sheep and cows fed a low-concentrate diet. But in this research, insulin concentration was not measured. We still require further work on serum hormone. The concentration of BUN in Group C was significantly lower than the other three groups $(p<0.01)$. BUN was an indicator of protein metabolism, and a lower concentration of BUN suggested a higher efficiency of protein synthesis in the body [31]. In present study, it could be that dietary MG/MP $=1.13$ achieved amino acid balance, so it presented a lowest $\mathrm{BUN}$ vaule. The balance between glucose and amino acids in the diet is very important for growing heifers. The amino acid nutritional status may depend on not only the status of glucose supply, but also amino acid composition in MP. The another problem with this approach is that it fails to take MP into account, some related problems needed to be studied deeply in future. To transport CHOL to cells throughout the body, and finally to the liver for bile acid synthesis is the main physiological functions of HDL [32]. Increasing dietary MG/MP linearly decreased the concentrations of CHOL and HDL-C ( $<<0.01)$. The reason for this result might be that higher dietary MG/MP can promote the secretion of insulin, which can inhibit the metabolic factors in the pituitary and decrease the concentrations of $\mathrm{CHOL}$ and HDL-C in the serum [11].

\section{Rumen fermentation parameters}

Ruminal pH reflects the balance between organic acid production in the rumen and acid removal through neutralization and absorption within the rumen [33]. As showed in Table 5, ruminal $\mathrm{pH}$ in the heifers ranged from 7.04 to 7.15 , which was far from subacute rumen acidosis (range from 5.2 to 5.6). Rumen $\mathrm{NH}_{3}-\mathrm{N}$ is the degradation product of protein and nonprotein $\mathrm{N}$ and is used for bacterial protein synthesis. Satter and Slyter [33] reported that the critical $\mathrm{NH}_{3}-\mathrm{N}$ concentration for microbial growth is 6 to $30 \mathrm{mg} / \mathrm{dL}$; otherwise, the

Table 4. Effects of increasing dietary MG/MP ratio on blood biochemical indices of 8 to 10-month-old heifers

\begin{tabular}{|c|c|c|c|c|c|c|}
\hline \multirow{2}{*}{ Items } & \multicolumn{4}{|c|}{ Dietary treatments ${ }^{1)}$ (MG/MP) } & \multirow{2}{*}{ SEM } & \multirow{2}{*}{ p-value } \\
\hline & $A(0.97)$ & $\mathrm{B}(1.07)$ & $C(1.13)$ & $D(1.26)$ & & \\
\hline $\mathrm{GLU}(\mathrm{mmol} / \mathrm{L})$ & 4.47 & 4.58 & 4.77 & 4.73 & 0.05 & 0.62 \\
\hline BUN (mmol/L) & $3.93^{\mathrm{a}}$ & $4.27^{\mathrm{a}}$ & $2.48^{b}$ & $3.30^{\mathrm{a}}$ & 0.18 & $<0.01$ \\
\hline $\mathrm{CHOL}(\mathrm{mmol} / \mathrm{L})$ & $3.54^{\mathrm{a}}$ & $2.69^{b}$ & $2.63^{b}$ & $2.34^{\mathrm{b}}$ & 0.12 & $<0.01$ \\
\hline $\mathrm{TG}(\mathrm{mmol} / \mathrm{L})$ & $0.25^{\mathrm{ab}}$ & $0.26^{\mathrm{a}}$ & $0.21^{b}$ & $0.23^{\mathrm{ab}}$ & 0.01 & 0.10 \\
\hline $\mathrm{HDL}-\mathrm{C}(\mathrm{mmol} / \mathrm{L})$ & $2.04^{a}$ & $1.73^{b}$ & $1.78^{b}$ & $1.66^{b}$ & 0.06 & $<0.01$ \\
\hline LDL-C (mmol/L) & 0.60 & 0.52 & 0.52 & 0.58 & 0.69 & 0.80 \\
\hline
\end{tabular}

MG, metabolizable glucose; MP, metabolizable protein; SEM, standard error of the mean; GLU, glucose; BUN, blood urea nitrogen; CHOL, cholesterol; TG, triglycerides; HDL-C, high density lipoprotein cholesterol; LDL-C, low density lipoprotein cholesterol.

1) Treatments were assigned to the four diets: MG/MP $=0.97,1.07,1.13$, and 1.26.

${ }^{a b}$ Different superscripts within the same row indicate a significant difference $(p<0.05)$. 
Table 5. Effects of increasing dietary MG/MP ratio on concentrations of rumen fermentation parameters of 8 to 10 -month-old heifers

\begin{tabular}{|c|c|c|c|c|c|c|}
\hline \multirow{2}{*}{ Items } & \multicolumn{4}{|c|}{ Dietary treatments $^{1)}(\mathrm{MG} / \mathrm{MP})$} & \multirow{2}{*}{ SEM } & \multirow{2}{*}{$\mathrm{p}$-value } \\
\hline & $A(0.97)$ & B (1.07) & C (1.13) & D (1.26) & & \\
\hline $\mathrm{pH}$ & 7.08 & 7.05 & 7.04 & 7.15 & 0.03 & 0.72 \\
\hline Total VFA (mmol/L) & $92.58^{\mathrm{a}}$ & $81.45^{\mathrm{ab}}$ & $69.82^{b}$ & $74.95^{b}$ & 4.12 & 0.04 \\
\hline Acetic acid (\%) & 73.01 & 72.36 & 74.00 & 72.16 & 0.35 & 0.23 \\
\hline Propionic acid (\%) & 17.37 & 17.66 & 17.34 & 18.00 & 0.23 & 0.78 \\
\hline Isobutyric acid (\%) & 0.93 & 1.10 & 0.95 & 1.31 & 0.06 & 0.07 \\
\hline Butyric acid (\%) & 6.78 & 6.77 & 5.80 & 6.34 & 0.23 & 0.39 \\
\hline Isovaleric acid (\%) & 1.32 & 1.51 & 1.41 & 1.62 & 0.06 & 0.42 \\
\hline Valeric acid (\%) & 0.58 & 0.60 & 0.49 & 0.66 & 0.03 & 0.23 \\
\hline Acetic/propionic & 4.32 & 4.15 & 4.48 & 3.65 & 0.26 & 0.22 \\
\hline $\mathrm{NH}_{3}-\mathrm{N}(\mathrm{mg} / 100 \mathrm{~mL})$ & 11.68 & 14.17 & 11.77 & 8.96 & 0.88 & 0.23 \\
\hline
\end{tabular}

MG, metabolizable glucose; MP, metabolizable protein; SEM, standard error of the mean; VFA, volatile fatty acid.

${ }^{1)}$ Treatments were assigned to the four diets: $M G / M P=0.97,1.07,1.13$, and 1.26.

${ }^{a b}$ Different superscripts within the same row indicate a significant difference $(p<0.05)$.

uncoupling effect of rumen fermentation will decrease the amount of microbial protein synthesis. In the present study, the difference of $\mathrm{NH}_{3}-\mathrm{N}$ concentrations in the four treatments were not obvious, indicating that the degradations of feed protein were similar among the four. Rumen volatile fatty acid (VFA) concentration reflects an integrated balance of organic acid, which is affected by the production, absorption, and turnover rate in the rumen [34]. Increasing dietary MG/MP linearly $(p<0.05)$ decreased the concentrations of total VFA, while there were no differences in the molar ratios of all VFAs $(p>0.05)$. Nocek et al [35] reported that starch and soluble saccharides were fermented in the rumen, which contributed to the quick accumulation of VFA. VFA can provide carbon skeletons for rumen microbes to synthesize MCP [36]. MCP accounted for $60 \%$ to $80 \%$ of the total protein in the intestine. When MG/MP was 1.13, the ADG of heifers was the quickest (Table 3), and the concentration of VFA was the lowest (Table 5). That's because it made VFA utilization rate high in treatment $\mathrm{C}$, and enhanced the MP synthesis. It also indicated that best dietary efficiency was maintained at this MG and $\mathrm{MP}$ ratio. Acetate to propionate ratio $(\mathrm{A} / \mathrm{P})$ and the ratio of non-glucogenic fatty acid to glucogenic fatty acid ratio (NGR) are two important indicators, which may decide the rumen fermentation pattern [37]. In this experiment, there was no significant difference in $\mathrm{A} / \mathrm{P}$ and NGR. It confirmed that different MG/MP could not change the rumen fermentation pattern.

\section{The relative amount of rumen microbes}

Increasing dietary MG/MP increased the relative amount of Butyrivibrio fibrisolvens and Ruminococcus albus $(\mathrm{p}<0.05)$ (Table 6). There was a trend $(\mathrm{p}=0.08)$ that as dietary MG/MP increased, an increase in the relative amount of Fibrobacter succinogenes was also observed. Ruminococcus albus, Ruminococcus flavefaciens and Fibrobacter succinogenes are regarded as the three major cellulose-decomposing bacteria [38]. Ruminococcus flavefaciens is even considered to be the strongest cellulose-decomposing bacteria [39]. In Table 1, acid detergent fiber (ADF) and neutral detergent fiber (NDF) content were lowered by increasing MG/MP ratios. Thus we speculate readily fermentable carbohydrates influenced the number of bacteria in the rumen. In the present study, the apparent digestibility of DM, CP, NDF, and ADF should be measured to support our hypothesis. Maeng et al [40] reported that the main effect of peptides for rumen bacteria is to increase the proliferation rate of ruminant bacteria and shorten the bac-

Table 6. Effects of increasing dietary MG/MP ratio on the relative amounts of rumen microbes in 8 to 10-month-old heifers

\begin{tabular}{|c|c|c|c|c|c|c|}
\hline \multirow{2}{*}{ Items } & \multicolumn{4}{|c|}{ Dietary treatments ${ }^{1)}$ (MG/MP) } & \multirow{2}{*}{ SEM } & \multirow{2}{*}{ p-value } \\
\hline & $A(0.97)$ & $B(1.07)$ & $C(1.13)$ & $\mathrm{D}(1.26)$ & & \\
\hline Fibrobacter succinogenes & $0.61^{b}$ & $0.64^{\mathrm{ab}}$ & $0.51^{b}$ & $1.00^{\mathrm{a}}$ & 0.08 & 0.08 \\
\hline Streptococcus bovis & 0.90 & 1.21 & 1.20 & 1.00 & 0.19 & 0.27 \\
\hline Ruminococcus albus & $0.57^{b}$ & $0.92^{\mathrm{ab}}$ & $0.92^{\mathrm{ab}}$ & $1.00^{\mathrm{a}}$ & 0.07 & 0.04 \\
\hline Ruminococcus flavefaciens & 0.72 & 1.02 & 1.28 & 1.00 & 0.08 & 0.13 \\
\hline Butyrivibrio fibrisolvens & $0.50^{b}$ & $0.69^{b}$ & $0.72^{b}$ & $1.00^{\mathrm{a}}$ & 0.24 & $<0.01$ \\
\hline
\end{tabular}

MG, metabolizable glucose; MP, metabolizable protein; SEM, standard error of the mean.

${ }^{1)}$ Treatments were assigned to the four diets: $M G / M P=0.97,1.07,1.13$, and 1.26.

${ }^{a b}$ Different superscripts within the same row indicate a significant difference $(p<0.05)$. 
terial cell cycle. We speculate the reason for the increase in the number of cellulose-decomposing bacteria also might be caused by the improvement in the concentrations of peptides in the rumen. However, peptides content was not measured in this research, future researches should take it into account. No other differences were observed for Streptococcus bovis (protein-degrading bacteria). The reason for this result might be that the growth of protein-degrading bacteria might be affected by several factors.

\section{CONCLUSION}

The results of this study indicate that changing dietary MG/MP resulted in improvement of ADG in heifers. A maximal growth rate for heifers that were between 8 to 10 months of age was achieved when dietary MG/MP was 1.13 . The increasing dietary MG/MP increased the number of cellulose-decomposing bacteria. It was concluded that an optimal dietary MG/MP level was 1.13 for 8 to 10 -month-old dairy heifers in this experiment, which contained a suitable amount of dietary protein and energy to maintain a synchronous state and lead to a higher efficiency of dietary protein and energy utilization in heifers. This finding will enhance current knowledge and help establish additional alternative dietary recommendations for dairy replacement heifers.

\section{CONFLICT OF INTEREST}

We certify that there is no conflict of interest with any financial organization regarding the material discussed in the manuscript.

\section{ACKNOWLEDGMENTS}

The authors would like to acknowledge the funding received to conduct this study from the project funded by the Top Talent Award Plan of Yangzhou University (2016), the National Science and Technology Support Program (12th FiveYear Plan), the Ministry of Science and Technology of China (Grant No. 2012BAD12B02-2) and the Priority Academic Program Development of Jiangsu Higher Education Institutions (PAPD). The authors would like to express their gratitude to the staffs at the Yangzhou University Experimental Farm for providing dairy heifers for this experiment. We also grateful to our colleagues, Ms Beibei Jiang, Mr. Yizhao Shen, Ms Huihui Cui, Mr Yu Pi and Mr Jian Gao at ruminant laboratory of YZU for their assistance with sampling and data analysis.

\section{REFERENCES}

1. Bar-Peled U, Robinzon B, Maltz E, et al. Increased weight gain and effects on production parameters of Holstein heifer calves that were allowed to suckle from birth to six weeks of age. J Dairy Sci 1997;80:2523-8.

2. Heinrichs AJ. Raising dairy replacements to meet the needs of the 21st century. J Dairy Sci 1993;76:3179-87.

3. Kertz AF, Chester-Jones H. Invited review: Guidelines for measuring and reporting calf and heifer experimental data. J Dairy Sci 2004;87:3577-80.

4. Whitlock BK, VandeHaar MJ, Silva LFP, Tucker HA. Effect of dietary protein on prepubertal mammary development in rapidly growing dairy heifers. J Dairy Sci 2002;85:1516-25.

5. Cantalapiedra-Hijar G, Peyraud JL, Lemosquet S, et al. Dietary carbohydrate composition modifies the milk $\mathrm{N}$ efficiency in late lactation cows fed low crude protein diets. Animal 2014; 8:275-85.

6. Preston TR, Leng RA. Matching ruminant production systems with available resources in the tropics and sub-tropics. Armidale, Australia: Penambul Books; 1987.

7. Sun HZ, Lu DX, Si Q. The research on the optimization of glucose nutrition for growing sheep. J Mong Husb 1999;1: 25-9. [in Chinese, English abstract].

8. Li SL, Feng YL, Mo F. The research on the effects of perfusion of different levels of glucose and casein into true stomach on the nitrogen metabolism regulation. J Anim Sci 1998;34:3-4 [in Chinese, English abstract].

9. Lu DX. Advances in enhancing nutrient utilization for ruminants by nutritional manipulation to reduce environmental contamination - review -. Asian-Australas J Anim Sci 2001; 14:395-401.

10. Taghizadeh A, Mesgaran MD, Valizadeh R, Shahroodi FE, Stanford K. Digestion of feed amino acids in the rumen and intestine of steers measured using a mobile nylon bag technique. J Dairy Sci 2005;88:1807-14.

11. Feng YL. Ruminant nutrition. Beijing, China: Science Press; 2004.

12. Lohakare JD, Sudekum KH, Pattanalk AK. Nutrition-induced changes of growth from birth to first calving and its impact on mammary development and first-lactation milk yield in dairy heifers: A review. Asian-Australas J Anim Sci 2012;25: 1338-50.

13. NRC (National Research Council). Nutrient requirements of dairy cattle. Washington, DC, USA: National Academy Press; 2001.

14. Han F. Study on estimation of the yields and absorption rate of propionice acid originated from fermentation of commonused feeds for sheep [master's thesis]. Hohhot, China: Inner Mongolian University of Agricultural; 2001.

15. Lan XQ. Determination of common-used feedstuffs MG values and influences of corn of different processing and forages associative on MG of dairy cows [master's thesis]. Hohhot, China: Inner Mongolian University of Agricultural; 2008.

16. Ørskov ER, McDonald I. The estimation of protein degrada- 
bility in the rumen from incubation measurements weighted according to rate of passage. J Agric Sci 1979;92:499-503.

17. Ge RF, Chen Q, Huo YJ, et al. Effects of different dietary metabolizable protein levels on growth and development, blood biochemical indices and body condition scores of 8 to 10month-old heifers. J Anim Nutr 2015;27:910-7 [in Chinese, English abstract].

18. Broderick GA, Kang JH. Automated simultaneous determination of ammonia and total amino acids in ruminal fluid and in vitro media. J Dairy Sci 1980;63:64-75.

19. Zhou J, Bruns MA, Tiedje JM. DNA recovery from soils of diverse composition. Appl Environ Microbiol 1996;62:31622.

20. Yang CB, Ying YL, Huang RL, et al. Principle and method of real-time RT-PCR. Immunological 2003;19:145-50 [in Chinese, English abstract].

21. Littell RC, Milliken GA, Stroup WW, Wolfinger RD. SAS system for mixed models. Cary, NC, USA: SAS Institute, Inc.; 1996.

22. Lascano GJ, Zanton GI, Heinrichs AJ. Effect of limit feeding high- and low-concentrate diets with Saccharomyces cerevisiae on digestibility and on dairy heifer growth and first-lactation performance. J Dairy Sci 2009;92:5100-10.

23. NRC (National Research Council). Nutrient requirements of dairy cattle. Washington DC, USA: National Academy Press; 1989.

24. Pirlo G, Capelletti M. Marchetto G. Effects of energy and protein allowances in the diet of prepubertal heifers on growth and milk production. J Dairy Sci 1997;80:730-9.

25. Ludden PA, Kerley MS. Amino acid and energy interrelationships in growing beef steers: I. The effect of level of feed intake on ruminal characteristics and intestinal amino acid flows. J Anim Sci 1997;75:2550-60.

26. Sun HZ, Lu DX, Zhang HY, et al. Effects of different ratio of dietary metabolizable glucose (MG) to metabolizable protein on glucose nutrition in growing-fishing sheep. J Anim Nutr 2001;13:43-8 [in Chinese, English abstract].

27. Su PC. Study on partitioning of proteins (amino acids) in white cashmere goats fed diets with different dietary metabolizable glucose levels [master's thesis]. Hohhot, China: Inner Mongolian University of Agricultural; 2002.

28. Fu C, Wang HR, Wang MZ, Yu LH, Huo YJ. Effects of different dietary metabolizable glucose levels on growth and develop- ment, nutrients digestibility and serum biochemical indices of 8 to 10-month-old heifers. Chinese J Anim Nutr 2014;26: 2615-22 [in Chinese, English abstract].

29. Murphy TA, Fluharty FL, Loerch SC. The influence of intake level and corn processing on digestibility and ruminal metabolism in steers fed all-concentrate diets. J Anim Sci 1994;72: 1608-15.

30. Jenny BF, Polan CE. Postprandial blood glucose and insulin in cows fed high grain. J Dairy Sci 1975;58,512-4.

31. Stanley CC, Williams CC, Jenny BF, et al. Effects of feeding milk replacer once versus twice daily on glucose metabolism in Holstein and Jersey calves. J Dairy Sci 2002;85:2335-43.

32. Sauar J, Skrede S, Erikssen J, Blomhoff JP. The relation between the levels of HDL cholesterol and the capacity for removal of triglycerides. J Intern Med 1980;208:199-203.

33. Satter LD, Slyter LL. Effect of ammonia concentration on rumen microbial protein production in vitro. Br J Nutr 1974; 32:199-208.

34. Wang HR, Chen Q, Chen LM, et al. Effects of dietary physically effective neutral detergent fiber content on the feeding behavior, digestibility, and growth of 8- to 10-month-old Holstein replacement heifers. J Dairy Sci 2017;1161-9.

35. Nocek JE, Russell JB. Protein and energy as an integrated system. Relationship of ruminal protein and carbohydrate availability to microbial synthesis and milk production. J Dairy Sci 1988;71:2070-107.

36. Sniffen CJ, O'Connor JD, Van Soest PJ, Fox DG, Russell JB. A net carbohydrate and protein system for evaluating cattle diets. I. Ruminal fermentation. J Anim Sci 1992;70:3551-61.

37. Lu DX. Theoretical system of glucose nutrition manipulation for ruminants and its application in feeding practice. Anim Husb Feed Sci 2010;31:402-9 [in Chinese, English abstract].

38. Krause DO, Russell JB. How many ruminal bacteria are there? J Dairy Sci 1996;79:1467-75.

39. Collings GF, Yokoyama MT. Gas-liquid chromatography for evaluating polysaccharide degradation by Ruminococcus flavefaciens C94 and Bacteroides succinogenes S85. Appl Environ Microbiol 1980;39:566-71.

40. Maeng WJ, Baldwin RL. Factors influencing rumen microbial growth rates and yields: Effect of amino acid additions to a purified diet with nitrogen from urea. J Dairy Sci 1976;59: 648-55. 